\title{
Typhoon-induced precipitation characterization over northern Japan: a case study for typhoons in 2016
}

\author{
Sridhara Nayak ${ }^{*}$ a and Tetsuya Takemi
}

\begin{abstract}
In August 2016, northern Japan was stuck by apparently unusual occurrence of the landfall of four typhoons and experienced record-breaking heavy precipitations. This study analyzed the extreme precipitations carried out by these four typhoons to understand their internal structure over northern Japan by computing the probability distributions of precipitation durations with their peak intensities exceeding a range of percentile thresholds starting from 70 to $99 \%$. The main focus was on the duration and size of the extreme precipitations together with the precipitation structure over northern Japan during the passage of each of these four typhoons through different latitudinal locations. To our knowledge, this is the first study to examine the long-lasting and widespread extreme precipitations carried by individual typhoon and such information are crucial for prevention of and protection from typhoon-related hazards over Japan. We find that the typhoons landfalled over Hokkaido region exhibit similar characteristics of precipitation duration, while the typhoon landfalled over Tohoku region shows relatively long-lived precipitation durations. However, all the four typhoons show a robust feature in the precipitation sizes over northern Japan. The occurrence of heavy precipitations with intensity higher than $20-30 \mathrm{~mm} \mathrm{~h}^{-1}$ is more frequent and last 6 to $9 \mathrm{~h}$ over northern Japan. These features may explain the excessive precipitations caused by each typhoon. The important information contained in this study is the duration and size of the precipitations induced by the typhoons vary depending on the landfalling region. However, the precipitation characteristics associated with all the three typhoons landfalled over Hokkaido show mostly robust features. This study gives a first step towards a description of the spatio-temporal characteristics of typhoon-induced precipitations and has an overall implication towards the future research that is needed for the assessment of typhoon-induced precipitation-related disasters in future warming climate.
\end{abstract}

Keywords: Precipitation characterization, Precipitation size, Precipitation duration, Typhoon, Radar-AMeDAS

\section{Introduction}

Tropical cyclones (TCs) are gigantic, destructive, and deadly disaster-spawning weather phenomena that bring very heavy precipitations and widespread flooding to coastal regions. According to the study of Pfahl and Wernli (2012), a high percentage of precipitation extremes (up to 80\%) is directly related to cyclones over the Mediterranean region, Newfoundland, near Japan, and over the South China Sea. Su et al. (2012) reported

\footnotetext{
* Correspondence: nayak@storm.dpri.kyoto-u.ac.jp

Disaster Prevention Research Institute, Kyoto University, Gokasho, Uji, Kyoto 6110011, Japan
}

\section{Springer Open}

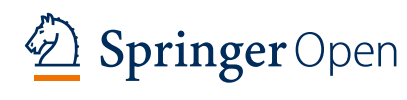

that the tropical cyclones over Taiwan bring about 70\% of extreme precipitations in July-October season. Kamahori and Arakawa (2018) evaluated typhoon-induced precipitation over Japan from the rain gauge observation for the period 1981-2010 and highlighted that the largest annual precipitation amount, which is $15 \%$ or more of the total annual precipitation, over western Japan is due to the TC activities. Thus, characterization of tropical cyclone-induced precipitation has been the focus of many studies not only for an individual tropical cyclone (e.g., Lin and Jeng 2000; Ishikawa et al. 2013; Chaithong et al. 2018) but also for the climatological period (e.g.,

(c) The Author(s). 2020 Open Access This article is licensed under a Creative Commons Attribution 4.0 International License, which permits use, sharing, adaptation, distribution and reproduction in any medium or format, as long as you give appropriate credit to the original author(s) and the source, provide a link to the Creative Commons licence, and indicate if changes were made. The images or other third party material in this article are included in the article's Creative Commons licence, unless indicated otherwise in a credit line to the material. If material is not included in the article's Creative Commons licence and your intended use is not permitted by statutory regulation or exceeds the permitted use, you will need to obtain permission directly from the copyright holder. To view a copy of this licence, visit http://creativecommons.org/licenses/by/4.0/. 
Cheung et al. 2018; Kim and Jain 2011; Su et al. 2012; Kamahori and Arakawa 2018).

Over the year, a large number of typhoons form over the western North Pacific region, and some of them became highly destructive, for example, Typhoon Vera (1959), Typhoon Mireille (1991), Typhoon Songda (2004), Typhoon Haiyan (2013), Typhoon Jebi (2018), and Typhoon Hagibis (2019) and caused severe and widespread damages by extreme precipitations (Oku et al. 2010; Mori et al. 2014; Mori and Takemi 2016; Takemi et al. 2016a, 2016b; Ito et al. 2016; Kanada et al. 2017; Takemi 2018; Takemi et al. 2019; Takemi 2019; Takemi and Ito 2020; Takemi and Unuma 2020). Such extreme typhoons strongly cause flash floods, landslides, and mudslides over large areas in a short period of time (Emanuel 2005; IPCC 2013, 2014; Takemi et al. 2016c; Guan et al. 2018). In the context of characterization of extreme precipitation events over Japan, several studies have been conducted in order to assess the spatial and temporal variability of precipitation amounts in different scales mostly either at the climatological period (e.g. Kanada et al. 2010, 2017) or at the baiu seasonal period (e.g., Duan et al. 2017; Yokoyama et al. 2017). Few studies have also been conducted for individual extremely heavy precipitation events over Japan to understand the precipitation distribution and their characteristics at convective and synoptic scale (Ishikawa et al. 2013; Takemi 2018; Kato et al. 2018; Tsuguti et al. 2019). However, to understand the severity of such disastrous events, studies are limited to get the information about the internal temporal-spatial precipitation structure in individual typhoons and particularly the duration and size of the precipitation within the typhoons.

In August 2016, northern Japan was stuck by apparently unusual occurrence of the landfall of four typhoons named as Typhoon Chanthu (T1607), Mindulle (T1609), Lionrock (T1610), and Kompasu (T1611). These were the series of typhoons moving northward near Japan, and three of them (except Typhoon Lionrock) landed on Hokkaido based on the Regional Specialized Meteorological Center (RSMC) Tokyo's best-track datasets. It was the first time till date that three typhoons landed on Hokkaido in a year. Typhoon Lionrock landed in the Pacific Ocean side of the Tohoku region in northern Japan. It was also for the first time in the history among the records (since 1951) available at Japan Meteorological Agency (JMA). All these typhoons made landfall with strong winds and brought heavy precipitations to the landfall regions and destroyed many lives and properties.

However, neither model nor observational data have yet been analyzed for individual typhoons that can explain the long-lasting and widespread extreme precipitations carried by a typhoon, and such information are crucial for prevention of and protection from typhoon- related hazards over Japan. Such assessments are also important in storm impacts for the proper interpretation of precipitation information, particularly to determine and map the vulnerability of the typhoon landfall region. In addition, the space and duration analysis of extreme precipitations provides robust results to determine the possible impacts and the monitoring of climate risks. We thus attempted to investigate the temporal and spatial characteristics of precipitation produced by typhoons to explore (1) the distribution, extremes, duration, size, and frequency of the precipitation induced by each typhoon, (2) the duration and size of heavy precipitations together with the precipitation duration versus peak intensity characteristics in each typhoon, and (3) the precipitation structure over northern Japan during the passage of each typhoon through different latitudinal locations. For this purpose, we used rain gauge-radar precipitation analysis data. The four typhoons in 2016 were chosen here, because they produced recordbreaking heavy precipitations in northern Japan. These cases are considered to be appropriate examples to understand the spatio-temporal characteristics of typhoon-induced extreme precipitations in northern Japan. In addition, recent analysis precipitation data produced by merging rain gauges and radars have a high spatial resolution, which is useful to quantitatively characterize extreme precipitations.

\section{Data and methods}

We analyzed the hourly observations of precipitation from the Radar Automated Meteorological Data Acquisition System (Radar-AMeDAS) analyzed precipitation datasets at $1 \mathrm{~km}$ resolution for each typhoon separately from each grid points over land in northern Japan (Fig. 1). The Radar-AMeDAS observations are the radar/rain gaugeanalyzed precipitation product available at $1 \mathrm{~km}$ grid over Japan which provides the composite radar-derived rainfall maps calibrated with rain gauges based on radar observation of rainfall intensity. We analyzed the Radar-AMeDAS data for 2 days for each typhoon separately keeping the typhoon landfall time (over Japanese land) as the center of the total selected duration. An overview of the lifetime period of each typhoon and the time period used in this study is descried in Table 1. The total sample points over the land were about $6 \mathrm{M}$ for each typhoon obtained from $560 \times 840$ grid points at $48 \mathrm{~h}$.

In this study, we reproduced the Kendon et al. (2012) methodology using all the grids points (land only) for each typhoon separately. We investigated the distribution, extremes, frequency, duration, and size of the precipitations induced by each typhoon with different thresholds (50th to 99th precipitation percentile). To compute the duration of the precipitations, we identified the independent precipitation durations above a 


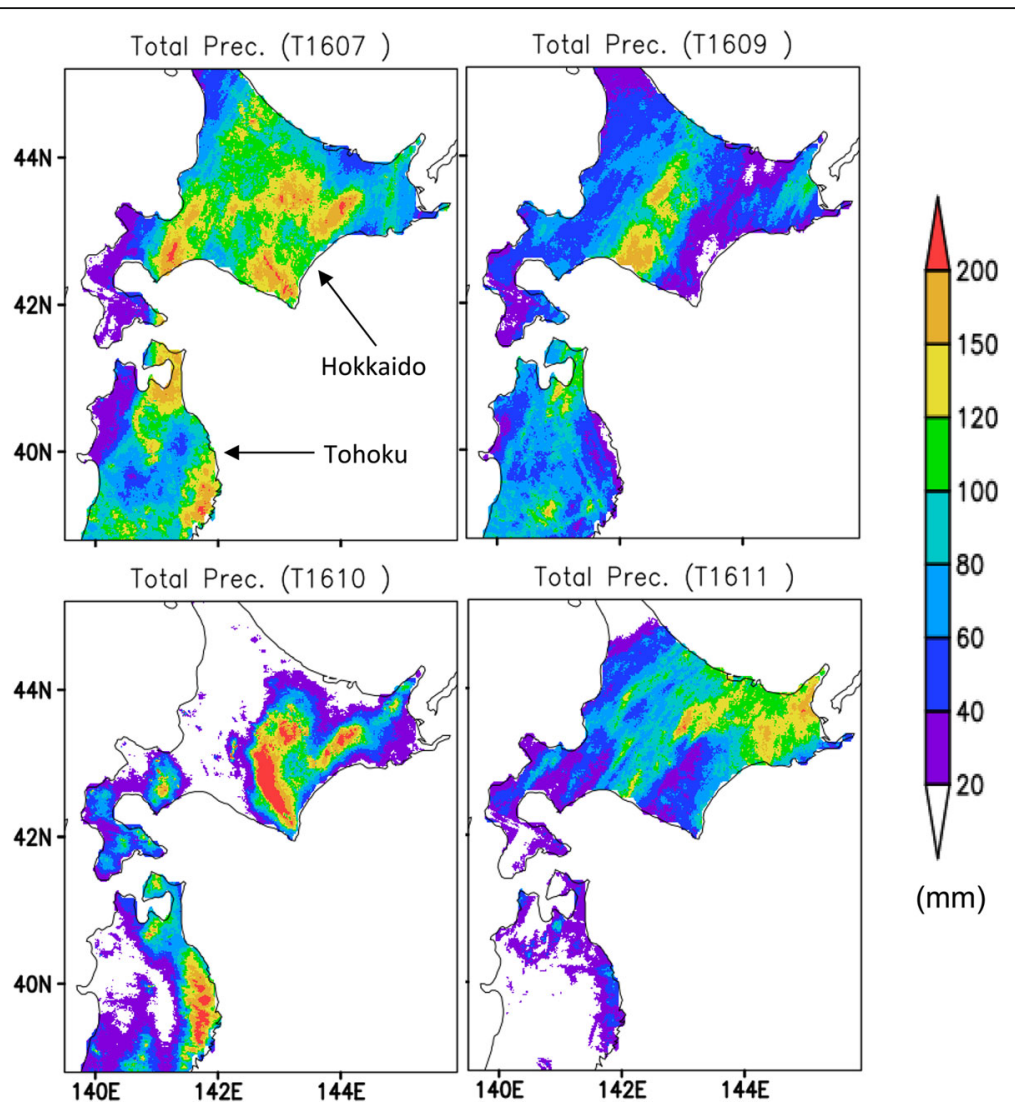

Fig. 1 Total precipitation (2 days accumulated) from a Typhoon Chanthu, b Typhoon Mindulle, c Typhoon Lionrock, and d Typhoon Kompasu

threshold in the hourly time series at each grid point. An independent duration is defined as continuous periods of precipitation exceeding the threshold. Then, we computed the mean and maximum intensity of precipitations in each duration and stratified the precipitation durations with intensity exceeding various precipitation thresholds in different duration bins with $1 \mathrm{~h}$ interval. Finally, the probability distributions are computed in each duration bin. To compute the size of the precipitations, we identified the independent precipitation cells above a threshold over the land at each hour. An independent cell is defined as the connected grids (diagonals are excluded) with precipitation intensity exceeding the threshold. We computed the mean and maximum intensity of precipitations in each cell and stratified the precipitation cells with intensity exceeding various precipitation thresholds in different cell bins with $1 \mathrm{~km}$ internal. Finally, the probability distributions are computed in each cell bin. The peak intensity in each precipitation duration is also examined to explore the relationship between the heaviest precipitation and its entire duration. To understand such temporal structure of the peak intensified precipitations carried by each typhoon, we computed the joint probability distribution of precipitation durations with their peak intensities exceeding a range of percentile thresholds starting from 70 to $99 \%$. Mathematically,

$$
P(A \cap B)=P(A) \cdot P(B)
$$

where $P$ is the probability, $A$ is the collection of independent precipitation durations, and $B$ is the peak intensity at each precipitation duration.

Table 1 Overview of each typhoon and time periods used in this study

\begin{tabular}{lllll}
\hline Typhoon name & Lifetime duration (in year 2016) & Maximum wind speed & Minimum pressure & Time period used (in year 2016) \\
\hline Chanthu (T1607) & 18UTC 13Aug-18UTC 17Aug & 55 knots & $980 \mathrm{hPa}$ & 00UTC 16Aug-23UTC 17Aug \\
Mindulle (T1609) & 06UTC 19Aug-03UTC 23Aug & 60 knots & $975 \mathrm{hPa}$ & 12UTC 21Aug-11UTC 23Aug \\
Lionrock (T1610) & 12UTC 21Aug-15UTC 30Aug & $90 \mathrm{knots}$ & $940 \mathrm{hPa}$ & 12UTC 29Aug-11UTC 31Aug \\
Kompasu (T1611) & O0UTC 20Aug-18UTC 21 Aug & $35 \mathrm{knots}$ & $994 \mathrm{hPa}$ & 06UTC 20Aug-05UTC 22Aug \\
\hline
\end{tabular}




\section{Results}

\section{Precipitation distribution}

The spatial distribution of total precipitation amounts during the passage of each typhoon over northern Japan is shown in Fig. 1. The results indicate that all the four typhoons brought heavy precipitations to the northern Japan. T1607 and T1610 brought total precipitations of greater than $200 \mathrm{~mm}$ to the landfall regions in Hokkaido and Tohoku regions, as already shown in the previous studies of Kanada et al. (2017) and Nayak and Takemi (2019a, 2019b). T1609 and T1611 brought relatively less precipitation and greater than $150 \mathrm{~mm}$ to some areas over Hokkaido.

Figure 2 shows the extremes, frequencies, durations, and size of hourly precipitations $(\geq 1 \mathrm{~mm})$ induced by each typhoon evaluated on the land regions shown in Fig. 1. The extremes are analyzed at different percentiles of precipitation intensities starting from 50th to 99.99th for each typhoon (Fig. 2a). We find that the extreme precipitation intensities (up to 95th percentile) carried by all the four typhoons are almost the same. The 99th percentile of all the four typhoons correspond to 20-30 $\mathrm{mm} \mathrm{h}^{-1}$ precipitation intensity, while the 99.99th value of T1610 corresponds to $72 \mathrm{~mm} \mathrm{~h}^{-1}$, and those of other three typhoons correspond to $40-60 \mathrm{~mm} \mathrm{~h}^{-1}$. The frequency distribution of the precipitation intensities induced by each typhoon is shown in Fig. 2 b. We find that the frequencies of precipitations with intensity up to $30 \mathrm{~mm} \mathrm{~h}^{-1}$ are similar for all the four typhoons. Stronger precipitations bought by T1610 have intensities above $120 \mathrm{~mm} \mathrm{~h}^{-1}$, while that carried by other three typhoons have intensities $55-75 \mathrm{~mm} \mathrm{~h}^{-1}$. Figure $2 \mathrm{c}$ shows the frequency distribution of group of precipitation durations induced by each typhoon. It shows that the precipitations carried by all the four typhoons are mostly shortlived and last up to $3 \mathrm{~h}$, while some precipitations last up to $12 \mathrm{~h}$. All the four typhoons also carried long-lived precipitations which last up to a day or longer, although the precipitations that last more than a day are not so frequent. Figure $3 \mathrm{~d}$ represents the frequency of group of precipitation sizes brought by each typhoon. It shows that all the four typhoons brought more frequent localized precipitations (within $10 \mathrm{~km}^{2}$ ) than widespread precipitations $\left(>100 \mathrm{~km}^{2}\right)$. It is noticed that all the three landfalling typhoons (i.e., the cases except T1610) over Hokkaido show similar characteristics of precipitation sizes.

\section{Precipitation intensity}

Figure 3 depicts the mean intensities in the different group of durations and sizes of typhoon-induced precipitations. It shows that most frequent short-lived precipitations correspond to about $6-10 \mathrm{~mm} \mathrm{~h}^{-1}$ mean intensity (Fig. 3a-d), while the long-lived precipitations (a) Percentiles of Prec. Intensity

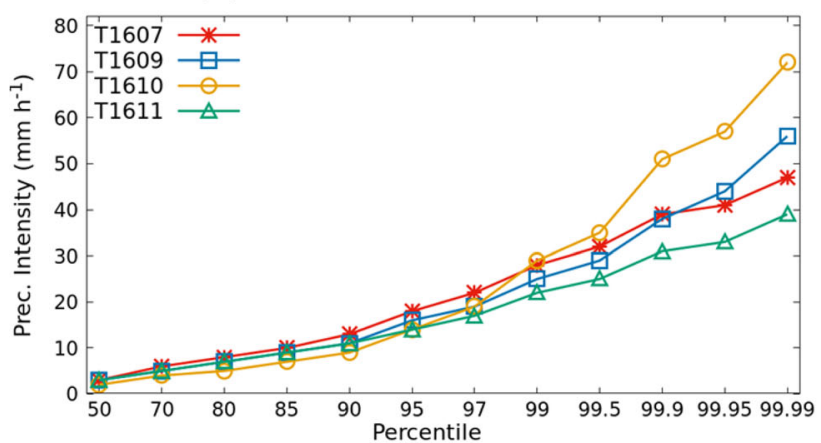

(c) Frequency of Prec. Duration

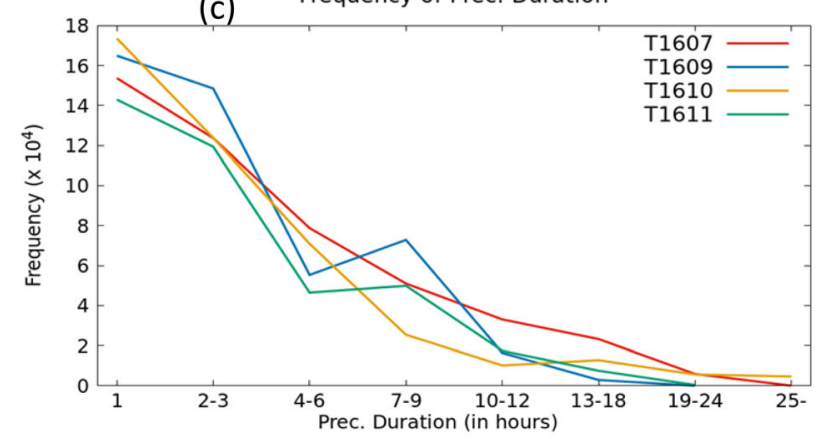

(b) Frequency of Prec. Intensity

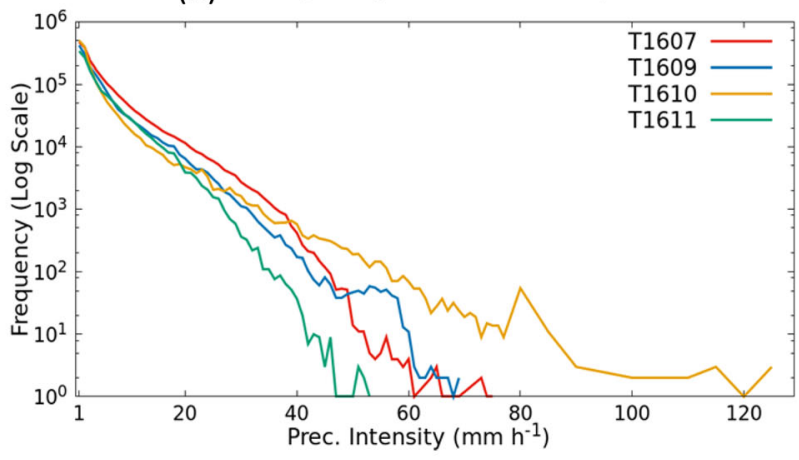

(d)

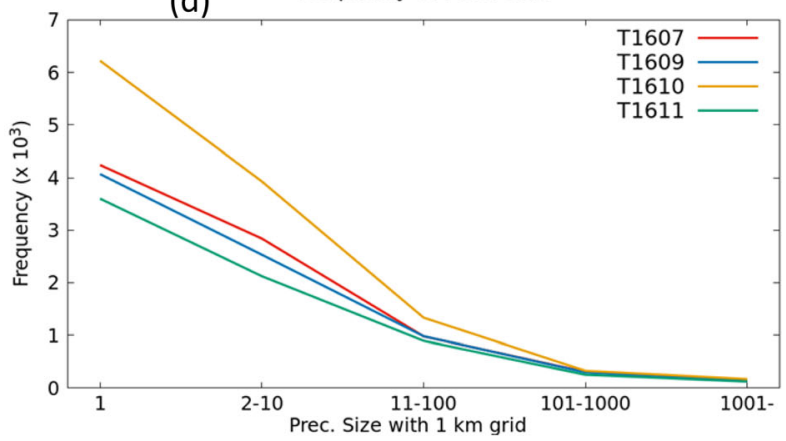

Fig. 2 Precipitation a percentiles, b frequency distribution, c duration, and $\mathbf{d}$ size. Results in (c) and (d) correspond to the frequency distributions of group of precipitation durations and precipitation sizes respectively 


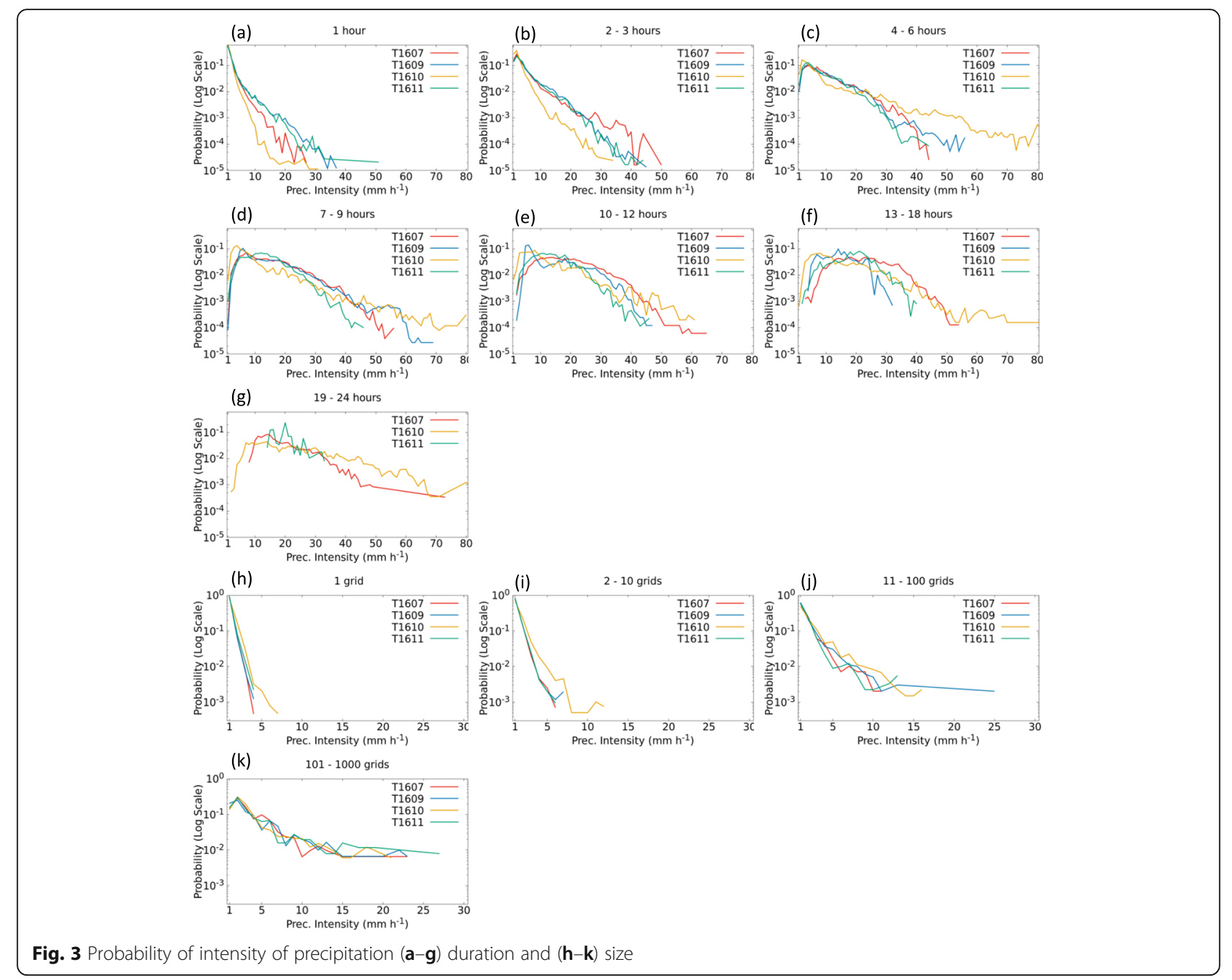

have intensity $15-20 \mathrm{~mm} \mathrm{~h}^{-1}$ (Fig. 3f, g). Longer duration (19-24 h) precipitations correspond up to $\sim 20 \mathrm{~mm} \mathrm{~h}^{-1}$ except for T1609 (Fig. 3g). The T1609 brought up to 18 $\mathrm{h}$ duration precipitation with mean intensity up to 30 $\mathrm{mm} \mathrm{h}^{-1}$, whereas the T1611 carried relatively longer durations (up to a day), but with same intensity. On the other hand, T1607 and T1610 brought long-lived stronger precipitations with intensity more than $70 \mathrm{~mm} \mathrm{~h}^{-1}$. The results of mean intensities in the precipitation sizes indicate that the intensity increases with the size of the precipitation (Fig. 3h-k). The localized precipitations (1-10 grids) correspond to mean intensity up to $10 \mathrm{~mm}$ $\mathrm{h}^{-1}$, while the widespread precipitation (11-1000 grids) shows higher intensity. All the four typhoons show mostly similar characteristics of mean intensity in precipitation sizes. These results indicate that longer duration precipitations are mostly stronger (Fig. 3e-g) compare to shorter duration precipitations (Fig. 3a, b), and smaller sized precipitations are weaker (Fig. 3h, i) compared to larger sized precipitation (Fig. 3j, k).

\section{Duration of heavy precipitations}

In this section, we analyzed the temporal features of the precipitations carried by each typhoon with intensity exceeding a range of percentile thresholds. This is shown in Fig. 4. Each curve in Fig. 4 depicts the probability distribution of precipitation durations with intensity exceeding a percentile threshold starting from 70 to $99 \%$. The results indicate that the short-duration precipitations (less than 3 h) occur more frequently compare to long-duration precipitations irrespective of percentile thresholds. For T1607, T1609, and T1611, extreme precipitations with intensity higher than 99th percentile tend to be short-lived and lasted up to $4 \mathrm{~h}$, while the precipitations with intensity higher than 90th percentile continued up to $6 \mathrm{~h}$ and that with intensity exceeding 70th percentile lasted up to $12 \mathrm{~h}$. For T1609, the heavy precipitations with intensity exceeding 99th percentile continued up to $6 \mathrm{~h}$, while those with intensities higher than 95th percentiles are long-lived and lasted more than $18 \mathrm{~h}$. These results indicate that the typhoons landfalling over Hokkaido region show almost 
same precipitation duration characteristics compared to the precipitation durations of the typhoon landfalled over Tohoku region.

\section{Size of heavy precipitations}

To assess the heavy precipitations in terms of its spatial structure, we investigated the size of precipitations carried by each typhoon with intensities exceeding various percentile thresholds. Figure 5 represents the probability distribution of precipitation sizes with intensity thresholds starting from 70 to $99 \%$. We find that all the four typhoons carried more frequent localized heavy precipitations compared to the widespread precipitations brought by these typhoons. Higher frequency of localized extreme precipitations associated with each typhoon is found to have spatial scales within $20 \mathrm{~km}^{2}$. There are also widespread precipitations larger than $100 \mathrm{~km}^{2}$, but not so frequent (Fig. 2d). However, the precipitation sizes up to $40 \mathrm{~km}^{2}$ areas with intensity exceeding $99^{\text {th }}$ percentile tend to be more frequent. All the four typhoons show similar characteristics of precipitation sizes, indicating a robust feature in the spatial structure of the typhoon-induced precipitations over northern Japan.

\section{Precipitation duration versus peak intensity}

In this section, we examined the duration-intensity characteristics of typhoon-induced precipitations from Eq. (1) by considering peak intensities in each precipitation duration exceeding a range of percentile thresholds (Fig. 6). We find that low peak precipitations (for instance exceeding the intensity 70th percentile) tend to be more shortlived, with a decreasing probability of high peak precipitations with increasing percentile thresholds. For the typhoons landfalled over Hokkaido, the probabilities of 8-9 $\mathrm{h}$ long precipitations are higher and carried high peak precipitations. These features may explain the excessive precipitations caused by each typhoon. For T1610, we find that all the peak precipitations lasted for $6 \mathrm{~h}$, and their probability tends to be higher than compare to long-lived precipitation. These results indicate that all the typhoons over northern Japan carry more frequent heavy precipitations with intensity higher than $20-30 \mathrm{~mm} \mathrm{~h}^{-1}$ for continuous 6 to $9 \mathrm{~h}$.

\section{Precipitation structure}

To understand the precipitation structure of each typhoon, we examined the area-averaged accumulated precipitations over northern Japan during the passage of each typhoon through different latitudinal locations
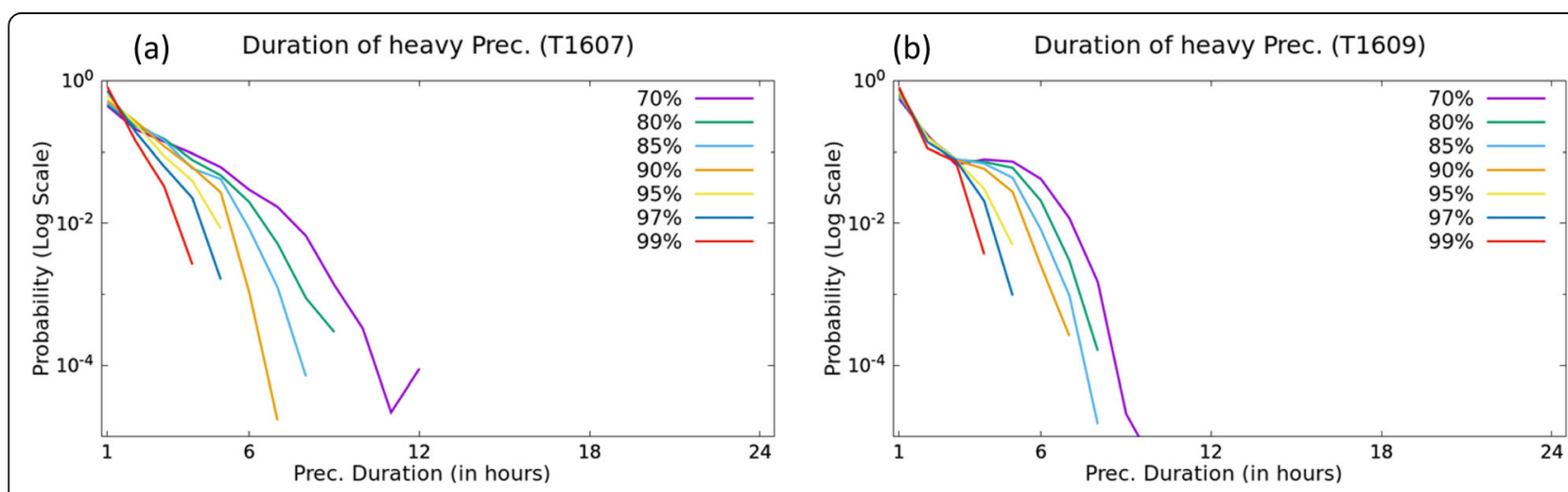

(c) Duration of heavy Prec. (T1610)

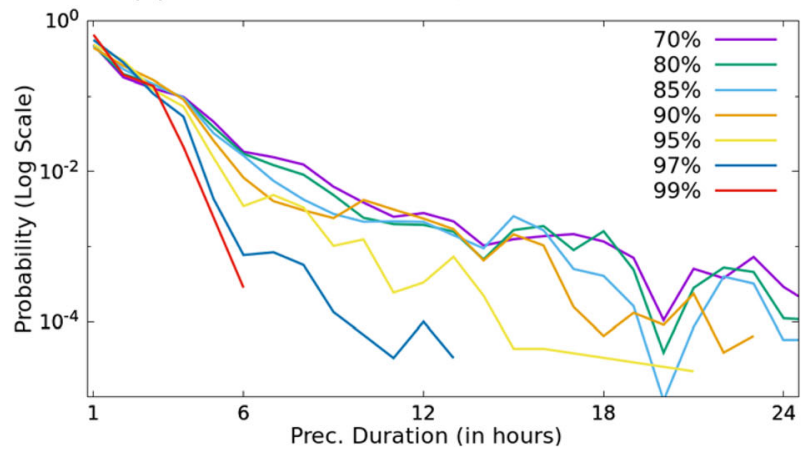

(d) Duration of heavy Prec. (T1611)

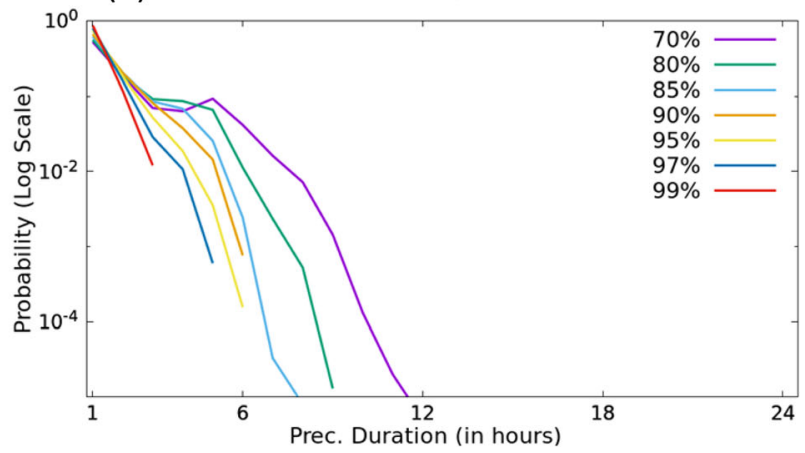

Fig. 4 Duration of heavy precipitations with different thresholds from a Typhoon Chanthu, b Typhoon Mindulle, c Typhoon Lionrock, and $\mathbf{d}$ Typhoon Kompasu. Results correspond to the probability 


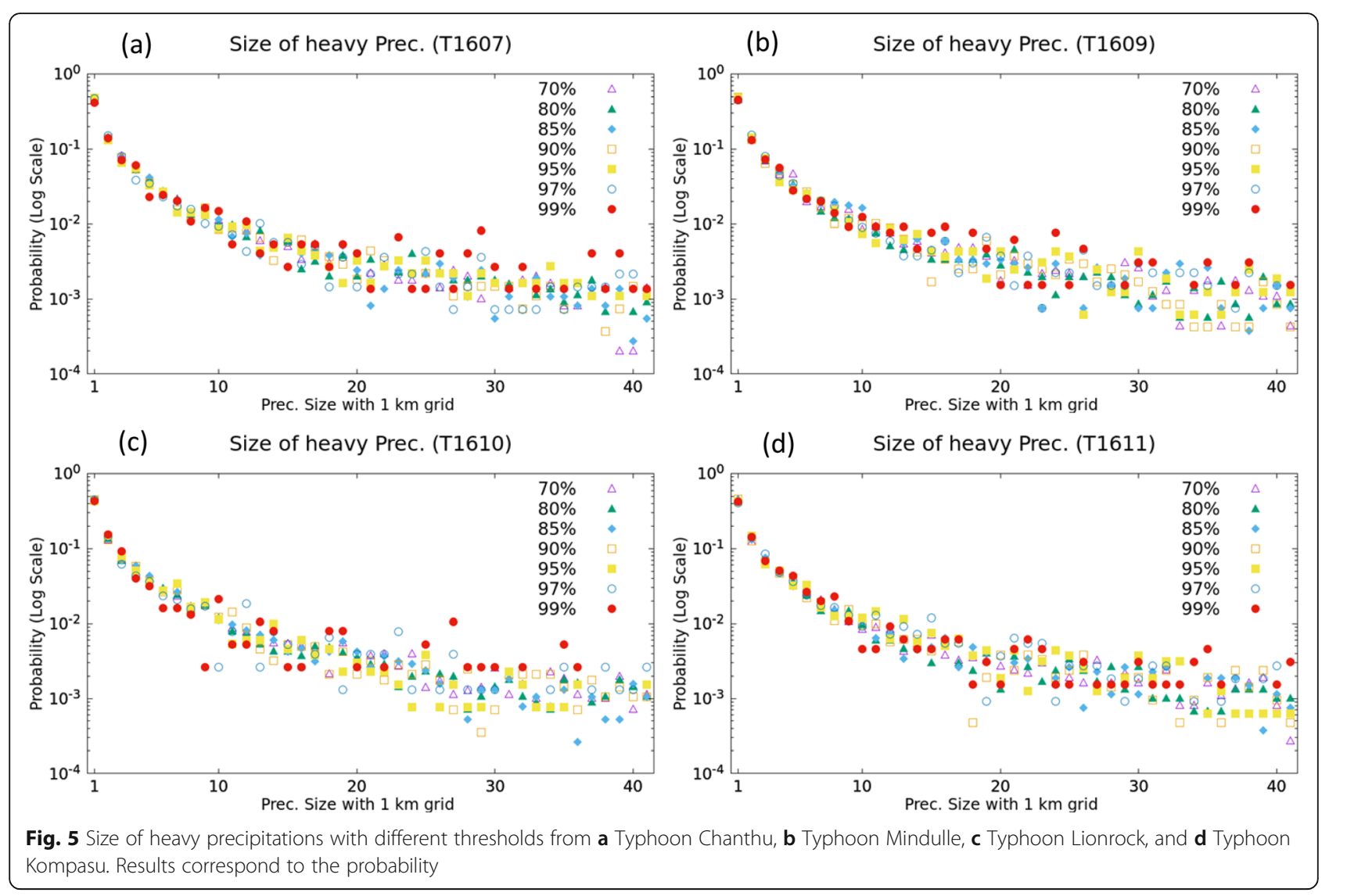

staring from 35 to $45 \mathrm{~N}$ (Fig. 7). We find that all the four typhoons during their location below $39 \mathrm{~N}$ do not bring substantial precipitations to the land over northern Japan. T1607 brought the highest amount of precipitation, while T1611 brought comparably the lowest amount.

Figure 8 shows the longitudinal averaged precipitations at different latitudes starting from 39 to $45 \mathrm{~N}$ during the passage of each typhoon through various latitudinal locations staring from 35 to 45 N. For T1607 and T1609, a strong propagating precipitation region is observed when the typhoon locations were at $38-41 \mathrm{~N}$ and at $43 \mathrm{~N}$, while for the T1610, the strong propagating signal was observed at $38-43 \mathrm{~N}$, and for T1611, it was $39-40 \mathrm{~N}$. This implies that all the four typhoons reaching $39 \mathrm{~N}$ carried large amount of precipitation to the land over northern Japan. It is noted that the precipitation areas generally extend to the north of the typhoon centers.

\section{Discussion}

This paper investigated the temporal and spatial characteristics of precipitations induced by four typhoons landfalled over northern Japan. We first focused on the distribution, extremes, duration, size, and frequency of the precipitations induced by each typhoon. Our results indicate that two typhoons (T1607 and T1610) carried relatively high amount of precipitations $(>200 \mathrm{~mm}$ ) to the landfall regions in Hokkaido and Tohoku regions while other two (T1609 and T16100) brought relatively less amount $(>150 \mathrm{~mm})$. T1610 brought stronger precipitations with intensity above $120 \mathrm{~mm} \mathrm{~h}^{-1}$, while others carried the same with $55-75 \mathrm{~mm} \mathrm{~h}^{-1}$. T1610 carried long-lived localized precipitation, while T1607 and T1611 brought short-lived widespread precipitation.

Next, we examined the duration and size of heavy precipitations associated with each typhoon. We find that the typhoons landfalled over Hokkaido region exhibit similar characteristics of precipitation duration (Fig. 4a, b, d), while the typhoon landfalled over Tohoku region shows relatively long-lived precipitation durations (Fig. 4c). However, all the four typhoons show a robust feature in the precipitation sizes over northern Japan. We also analyzed the duration and size of heavy precipitations with different thresholds starting from 70 to $99 \%$ considering three typhoons (Typhoon Chanthu, Typhoon Mindulle, and Typhoon Kompasu) together over Hokkaido and shown in Fig. 9. Results indicated that in the combined case over Hokkaido, the typhoon-induced precipitations with intensity higher than 95th percentile lasted up to $6 \mathrm{~h}$, while the precipitations with intensity higher than 50 th percentile tend to be long-lived and continued up to $12 \mathrm{~h}$ (Fig. 9a). The size of the typhoon-induced precipitations in the 


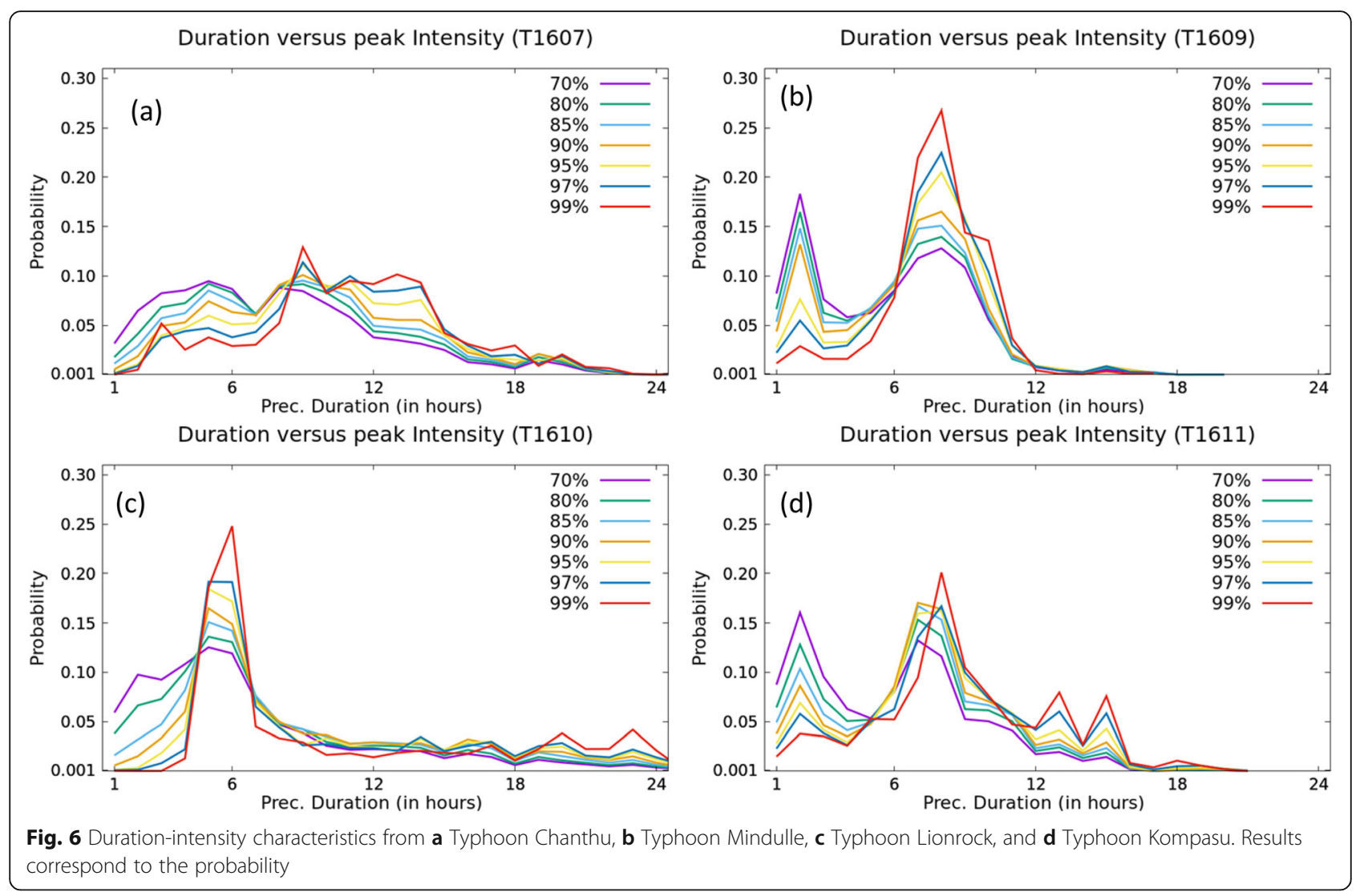

combined case over Hokkaido showed more frequent localized heavy precipitations with spatial scales within 20 $\mathrm{km}^{2}$ (Fig. 9b). Overall results indicated that the characteristics of precipitation duration and sizes in the combined cases are mostly same as of individual typhoon landfalled over Hokkaido. To understand the mechanism on why do the typhoons landfalled over Hokkaido region exhibit similar precipitation duration characteristics, we analyzed the atmospheric water vapor from the 3 hourly forecast
Japanese Reanalysis (JRA-55, Kobayashi et al. 2015) data of JMA during the passage of each individual typhoon over northern Japan (Fig. 10). We find that the supply of atmospheric moisture plays an important rule to maintain the precipitation duration. A closer investigation in Fig. 10 shows that all the four typhoon supplied continuous moisture and formed peak. This possibly brought continuous precipitations up to certain duration and then decreased as the moisture supply gradually decreased in time (Fig.

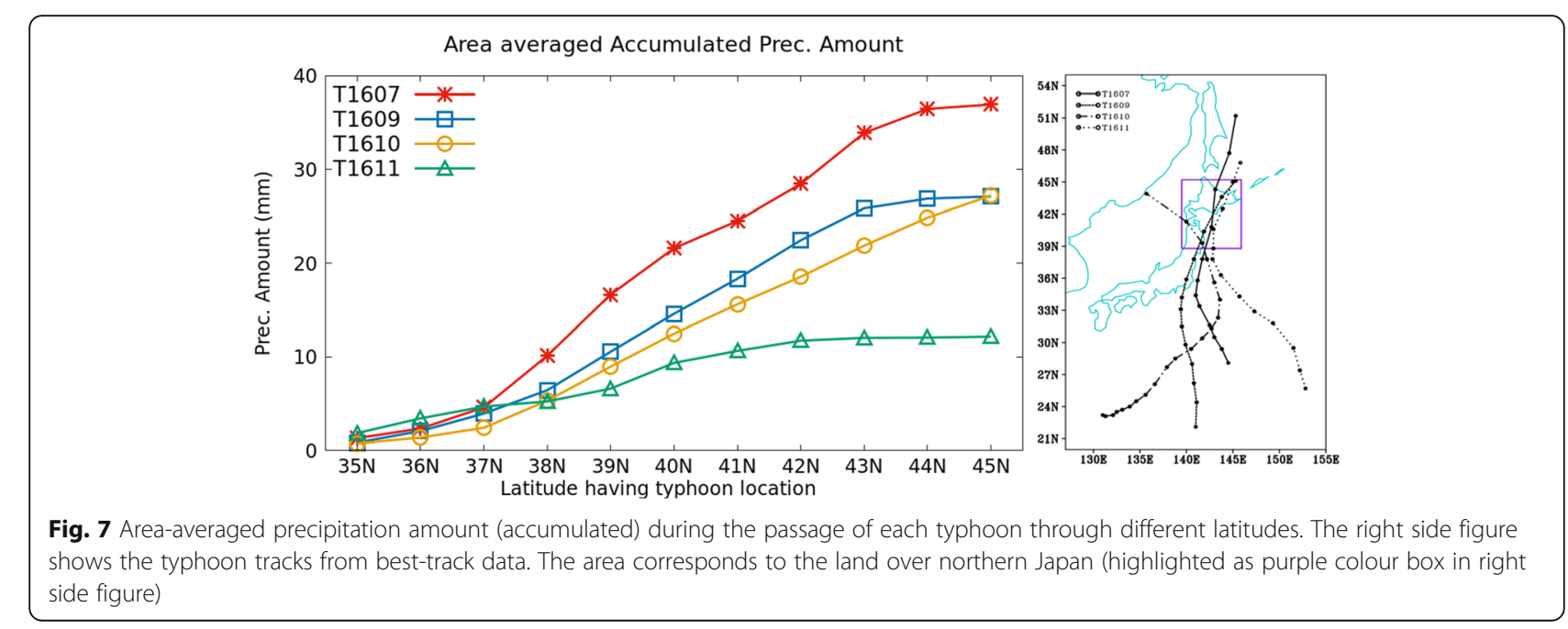



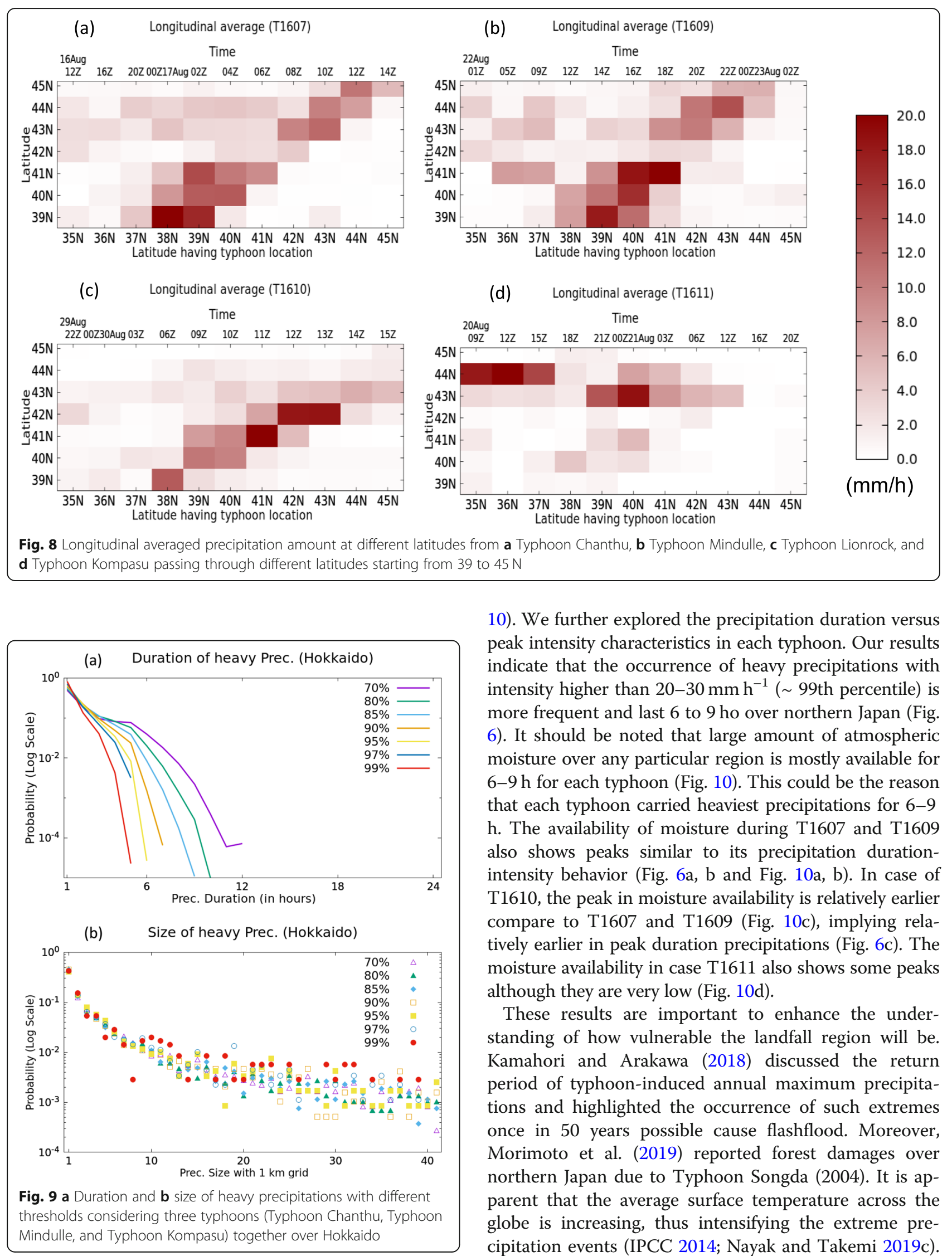

10). We further explored the precipitation duration versus peak intensity characteristics in each typhoon. Our results indicate that the occurrence of heavy precipitations with intensity higher than $20-30 \mathrm{~mm} \mathrm{~h}^{-1}$ ( 99th percentile) is more frequent and last 6 to 9 ho over northern Japan (Fig. 6). It should be noted that large amount of atmospheric moisture over any particular region is mostly available for 6-9 h for each typhoon (Fig. 10). This could be the reason that each typhoon carried heaviest precipitations for 6-9 h. The availability of moisture during T1607 and T1609 also shows peaks similar to its precipitation durationintensity behavior (Fig. 6a, b and Fig. 10a, b). In case of T1610, the peak in moisture availability is relatively earlier compare to T1607 and T1609 (Fig. 10c), implying relatively earlier in peak duration precipitations (Fig. 6c). The moisture availability in case T1611 also shows some peaks although they are very low (Fig. 10d).

These results are important to enhance the understanding of how vulnerable the landfall region will be. Kamahori and Arakawa (2018) discussed the return period of typhoon-induced annual maximum precipitations and highlighted the occurrence of such extremes once in 50 years possible cause flashflood. Moreover, Morimoto et al. (2019) reported forest damages over northern Japan due to Typhoon Songda (2004). It is apparent that the average surface temperature across the globe is increasing, thus intensifying the extreme precipitation events (IPCC 2014; Nayak and Takemi 2019c). 
(a) Duration versus peak precipitable water (T1607)

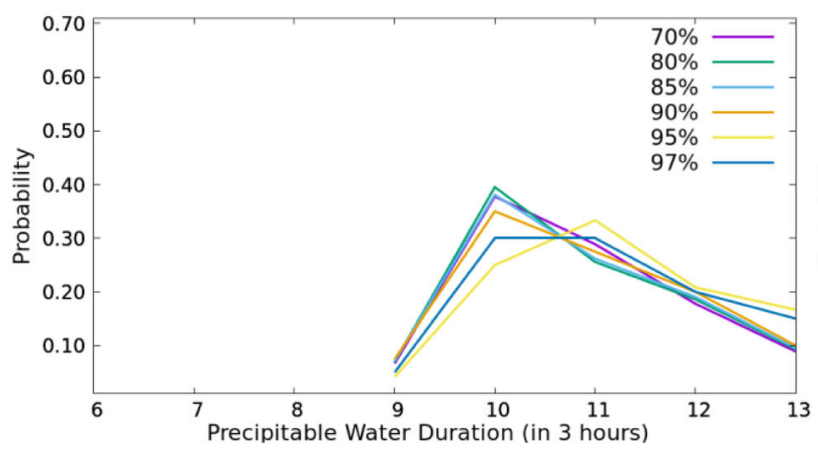

(c) Duration versus peak precipitable water (T1610)

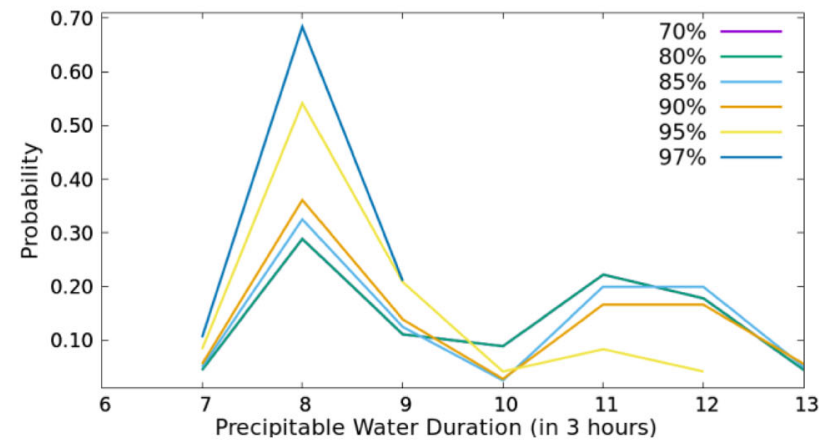

(b) Duration versus peak precipitable water (T1609)

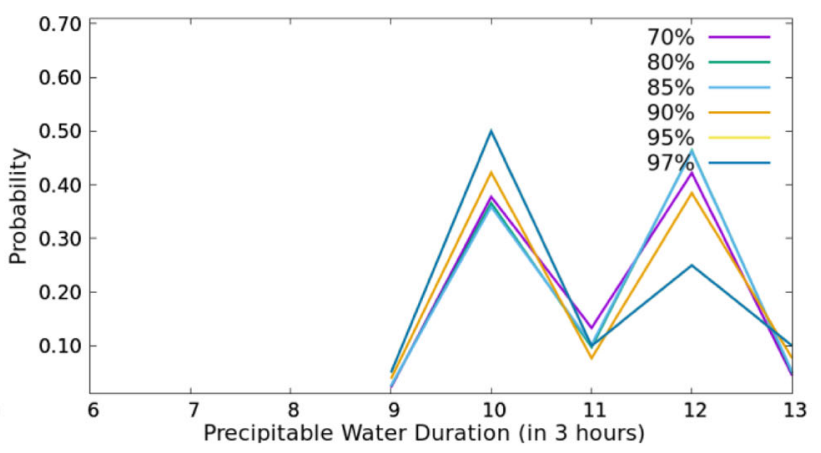

(d) Duration versus peak precipitable water (T1611)

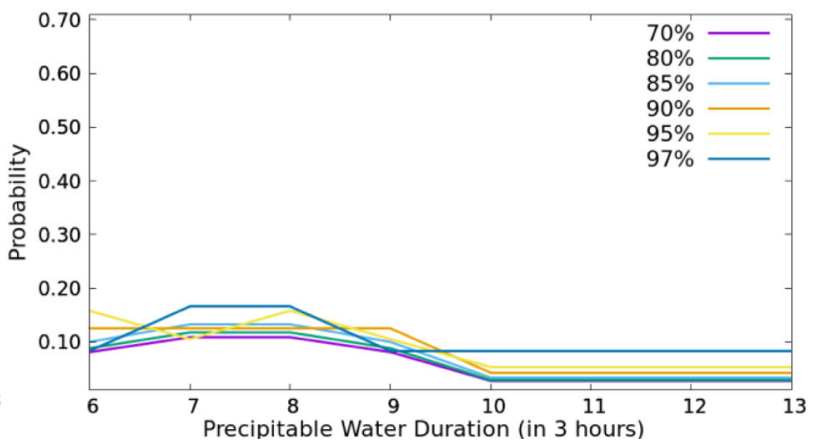

Fig. 10 Atmospheric water vapour from the 3 hourly forecast JRA-55 dataset during the passage of a Typhoon Chanthu, b Typhoon Mindulle, c Typhoon Lionrock, and d Typhoon Kompasu

Several studies also highlighted that the extreme weather events such as typhoons, floods, and heavy precipitation events over Japan would be more intense due to warming (Nayak and Dairaku 2016; Kanada et al. 2017; Nayak et al. 2018; Kawase et al. 2020). Likewise, various studies reported that typhoons in future warming climate are expected to carry more precipitations to landfall regions (Takemi et al. 2016a; Kanada et al. 2017; Nayak and Takemi 2019a). To reveal and better characterize such features, application of climate model is needed. So, we believe that our study gives a first step towards a description of the spatio-temporal characteristics of typhoon-induced precipitations and can be used to evaluate the model results for the assessment of typhoon-induced precipitation-related disasters in future warming climate.

\section{Conclusions}

In this study, we examined the long-lasting and widespread extreme precipitations carried by four typhoons in August 2016 over northern Japan from the very high spatial resolution rain gauge-radar precipitation analysis data. The results indicate that the durations of the extreme precipitations induced by the three typhoons landfalling over Hokkaido region exhibit similar features, while the typhoon landfalled over Tohoku region shows relatively long-lived extreme precipitation durations. However, all the four typhoons show similar spatial structure of the typhoon-induced precipitations over northern Japan. All the four typhoons also carried longlived precipitations which last up to a day or longer and more frequent localized precipitations than widespread precipitations. The frequencies of precipitations with intensity up to $\sim 30 \mathrm{~mm} \mathrm{~h}^{-1}$ are similar for all the four typhoons. The occurrence of extremely heavy precipitations (higher than 99th percentile) carried out by all the four typhoons is mostly last up to 6-9 h. These features may explain the excessive precipitations caused by each typhoon. The results of the precipitation structure during the passage of each typhoon through different latitudinal locations indicate that all the four typhoons reproduce heavy precipitations over the land in northern Japan when they reach at $39 \mathrm{~N}$. Overall, the important information contained in this study is the duration and size of the precipitations induced by the four typhoons vary depending on the landfalling region. However, the precipitation characteristics associated with all the typhoons landfalled over Hokkaido show mostly robust features. More research is needed to get a better understanding of the processes involved in typhoon-induced precipitation by using some very high resolution climate model and their response to future climate change. 


\section{Abbreviations}

TC: Tropical cyclone; Radar-AMeDAS: Radar Automated Meteorological Data Acquisition System; JMA: Japan Meteorological Agency; T1607: Typhoon Chanthu; T1609: Typhoon Mindulle; T1610: Typhoon Lionrock;

T1611: Typhoon Kompasu; IPCC: Intergovernmental Panel on Climate Change; RSMC: Regional Specialized Meteorological Center

\section{Acknowledgements}

This study was supported by the TOUGOU program and funded by the Ministry of Education, Culture, Sports, Science, and Technology, Government of Japan. Japan Meteorological Agency (JMA) is acknowledged for providing Radar/Rain gauge-Analyzed Precipitation product.

\section{Authors' contributions}

SN proposed the topic, designed the study, analyzed the data, and drafted the manuscript. $T$ helped in the interpretation and the construction of the manuscript. All authors read and approved the final manuscript.

\section{Funding}

This study was supported by the TOUGOU program funded by the Ministry of Education, Culture, Sports, Science, and Technology, Government of Japan.

\section{Availability of data and materials}

The Radar/Rain gauge-Analyzed Precipitation dataset supporting the conclusions of this article is obtained from the Japan Meteorological Agency (JMA, www.jmbsc.or.jp).

\section{Competing interests}

The authors declare that they have no competing interest.

Received: 5 March 2020 Accepted: 25 June 2020

Published online: 12 August 2020

\section{References}

Chaithong T, Komori D, Sukegawa Y, Touge Y, Mitobe Y, Anzai S (2018) Landslides and precipitation characteristics during the typhoon Lionrock in Iwate prefecture, Japan. Int J 14(44):109-114

Cheung HM, Ho CH, Jhun JG, Park DSR, Yang S (2018) Tropical cyclone signals on rainfall distribution during strong vs. weak Changma/Baiu years. Clim Dyn 51(5-6):2311-2320

Duan W, He B, Sahu N, Luo P, Nover D, Hu M, Takara K (2017) Spatiotemporal variability of Hokkaido's seasonal precipitation in recent decades and connection to water vapour flux. Int J Climatol 37(9):3660-3673

Emanuel K (2005) Increasing destructiveness of tropical cyclones over the past 30 years. Nature 436(7051):686-688

Guan S, Li S, Hou Y, Hu P, Liu Z, Feng J (2018) Increasing threat of landfalling typhoons in the western North Pacific between 1974 and 2013. Int J Appl Earth Obs Geoinf. https://doi.org/10.1016/j.jag.2017.12.017

IPCC (2013) Climate change 2013: The physical science basis. Contribution of Working Group I to the Fifth Assessment Report of the Intergovernmental Panel on Climate Change. In: Stocker TF, Qin D, Plattner G-K, Tignor M, Allen SK, Boschung J, Nauels A, Xia Y, Bex V, Midgley PM (eds) . Cambridge University Press, Cambridge, United Kingdom and New York, p 1535

IPCC (2014) Climate change 2014: Impacts, adaptation, and vulnerability. Part A: Global and Sectoral Aspects. Contribution of Working Group II to the Fifth Assessment Report of the Intergovernmental Panel on Climate Change. In: Field CB, Barros VR, Dokken DJ, Mach KJ, Mastrandrea MD, Bilir TE, Chatterjee M, Ebi KL, Estrada YO, Genova RC, Girma B, Kissel ES, Levy AN, MacCracken S, Mastrandrea PR, White LL (eds). Cambridge University Press, Cambridge, United Kingdom and New York, p 1132

Ishikawa H, Oku Y, Kim S, Takemi T, Yoshino J (2013) Estimation of a possible maximum flood event in the Tone River basin, Japan caused by a tropical cyclone. Hydrol Process 27(23):3292-3300

Ito R, Takemi T, Arakawa O (2016) A possible reduction in the severity of typhoon wind in the northern part of Japan under global warming: a case study. SOLA 12:100-105

Kamahori H, Arakawa O (2018) Tropical cyclone induced precipitation over Japan using observational data. SOLA 14:165-169

Kanada S, Nakano M, Kato T (2010) Climatological characteristics of daily precipitation over Japan in the Kakushin regional climate experiments using a non-hydrostatic 5-km-mesh model: comparison with an outer global 20km-mesh atmospheric climate model. SOLA 6:117-120

Kanada S, Tsuboki K, Aiki H, Tsujino S, Takayabu I (2017) Future enhancement of heavy rainfall events associated with a typhoon in the Midlatitude Regions. SOLA 13:246-251

Kato R, Shimose Kl, Shimizu S (2018) Predictability of precipitation caused by linear precipitation systems during the July 2017 Northern Kyushu Heavy Rainfall Event using a cloud-resolving numerical weather prediction model. J Disaster Res 13(5):846-859

Kawase H, Imada Y, Tsuguti H, Nakaegawa T, Seino N, Murata A, Takayabu I (2020) The Heavy Rain Event of July 2018 in Japan Enhanced by Historical Warming. Bull. Amer Meteor Soc 101:S109-S114

Kendon EJ, Roberts NM, Senior CA, Roberts MJ (2012) Realism of rainfall in a very high-resolution regional climate model. J Clim 25(17):5791-5806

Kim JS, Jain S (2011) Precipitation trends over the Korean peninsula: typhooninduced changes and a typology for characterizing climate-related risk. Environ Res Lett 6(3):034033

Kobayashi S, Ota Y, Harada Y, Ebita A, Moriya M, Onoda H, Onogi K, Kamahori H, Kobashi C, Hosaka M, Endo H, Miyaoka K (2015) The JRA-55 reanalysis: general specifications and basic characteristics. J Meteor Soc Japan, Ser II 93(1):5-48

Lin ML, Jeng FS (2000) Characteristics of hazards induced by extremely heavy rainfall in Central Taiwan-Typhoon Herb. Eng Geol 58(2):191-207

Mori N, Kato M, Kim S, Mase H, Shibutani Y, Takemi T, Tsuboki K, Yasuda T (2014) Local amplification of storm surge by Super Typhoon Haiyan in Leyte Gulf. Geophys Res Lett 41(14):5106-5113

Mori N, Takemi T (2016) Impact assessment of coastal hazards due to future changes of tropical cyclones in the North Pacific Ocean. Weather Clim Extremes 11:53-69

Morimoto J, Nakagawa K, Takano KT, Aiba M, Oguro M, Furukawa Y, Mishima Y, Ogawa K, Ito R, Takemi T, Nakamura F, Peterson CJ (2019) Comparison of vulnerability to catastrophic wind between Abies plantation forests and natural mixed forests in northern Japan. Forestry 92(4):436-443

Nayak S, Dairaku K (2016) Future changes in extreme precipitation intensities associated with temperature under SRES A1B scenario. Hydrol Res Lett 10(4): 139-144

Nayak S, Dairaku K, Takayabu I, Suzuki-Parker A, Ishizaki NN (2018) Extreme precipitation linked to temperature over Japan: current evaluation and projected changes with multi-model ensemble downscaling. Clim Dyn 51(11-12):4385-4401. https://doi.org/10.1007/s00382-017-3866-8

Nayak S, Takemi T (2019a) Quantitative estimations of hazards resulting from Typhoon Chanthu (2016) for assessing the impact in current and future climate. Hydrol Res Lett 13(2):20-27

Nayak S, Takemi T (2019b) Dynamical downscaling of Typhoon Lionrock (2016) for assessing the resulting hazards under global warming. J Meteor Soc Japan 97(1):69-88. https://doi.org/10.2151/jmsj.2019-003

Nayak S, Takemi T (2019c) Dependence of extreme precipitable water events on temperature. Atmósfera 32(2):159-265. https://doi.org/10.20937/ATM.2019.32. 02.06

Oku Y, Takemi T, Ishikawa H, Kanada S, Nakano M (2010) Representation of extreme weather during a typhoon landfall in regional meteorological simulations: a model intercomparison study for Typhoon Songda (2004). Hydrol Res Lett 4:1-5

Pfahl S, Wernli H (2012) Quantifying the relevance of cyclones for precipitation extremes. J Clim 25(19):6770-6780

Su SH, Kuo HC, Hsu LH, Yang YT (2012) Temporal and spatial characteristics of typhoon extreme rainfall in Taiwan. J Meteorol Soc Japan Ser II 90(5):721-736

Takemi T (2018) Importance of terrain representation in simulating a stationary convective system for the July 2017 Northern Kyushu Heavy Rainfall case. SOLA 14:153-158. https://doi.org/10.2151/sola.2018-027

Takemi T (2019) Impacts of global warming on extreme rainfall of a slow-moving typhoon: a case study for Typhoon Talas (2011). SOLA. https://doi.org/10. 2151/sola.2019-023

Takemi T, Ito R (2020) Benefits of high-resolution downscaling experiments for assessing strong wind hazard at local scales in complex terrain: a case study of Typhoon Songda (2004). Prog Earth Planetary Sci 7(1):1-16

Takemi T, Ito R, Arakawa O (2016a) Effects of global warming on the impacts of Typhoon Mireille (1991) in the Kyushu and Tohoku regions. Hydrol Res Lett 10(3):81-87

Takemi T, Ito R, Arakawa O (2016b) Robustness and uncertainty of projected changes in the impacts of Typhoon Vera (1959) under global warming. Hydrol Res Lett 10(3):88-94 
Takemi T, Okada Y, Ito R, Ishikawa H, Nakakita E (2016c) Assessing the impacts of global warming on meteorological hazards and risks in Japan: philosophy and achievements of the SOUSEI program. Hydrol Res Lett 10(4):119-125

Takemi T, Unuma T (2020) Environmental factors for the development of heavy rainfall in the eastern part of Japan during Typhoon Hagibis (2019). SOLA 16: 30-36. https://doi.org/10.2151/sola.2020-006

Takemi T, Yoshida T, Yamasaki S, Hase K (2019) Quantitative estimation of strong winds in an urban district during Typhoon Jebi (2018) by merging mesoscale meteorological and large-eddy simulations. SOLA. https://doi.org/10.2151/ sola.2019-005

Tsuguti H, Seino N, Kawase H, Imada Y, Nakaegawa T, Takayabu I (2019) Meteorological overview and mesoscale characteristics of the Heavy Rain Event of July 2018 in Japan. Landslides 16(2):363-371

Yokoyama C, Takayabu YN, Horinouchi T (2017) Precipitation characteristics over East Asia in early summer: Effects of the subtropical jet and lowertropospheric convective instability. J Clim 30(20):8127-8147

\section{Publisher's Note}

Springer Nature remains neutral with regard to jurisdictional claims in published maps and institutional affiliations.

\section{Submit your manuscript to a SpringerOpen ${ }^{\circ}$ journal and benefit from:}

- Convenient online submission

- Rigorous peer review

- Open access: articles freely available online

- High visibility within the field

Retaining the copyright to your article

Submit your next manuscript at $\boldsymbol{\triangleright}$ springeropen.com 